\title{
MANAGEMENT UNDER LIMITED INFORMATION - THE MEASUREMENT OF OFF-BALANCE SHEET ASSETS AT HUNGARIAN FIRMS
}

\section{Juhász, P.}

Relying on three questionnaire-based surveys from 2004, 2009 and 2013, each covering around 300 top financial managers of different Hungarian manufacturing and service companies, this article analyzes how the perception and measurement of intellectual capital (IC) elements has changed. Instead of focusing on stock exchange prices or case studies of individual firms, this research is unique for using a database on the opinion of top managers over a decade. After the managers, IC has slightly gained importance giving 48-51 percent of the firm value during the years analyzed, still, most companies give little attention to measuring these items correctly. This is dangerous, as by just focusing on traditional accounting measures or relying on outdated methods, top managers are less likely to take shareholder value maximizing decisions. Encouragingly, those who measure do it better: book value has lost popularity while more appropriate market value based estimates have gained importance.

Keywords: valuation; invested capital; intellectual capital JEL classification: G32, M41

\section{Introduction}

While literature paid increased attention to intellectual capital (IC) elements (strategy, human resource, business connections) during the last decades, managers might not have done so in emerging countries. This article investigates how the appreciation of the off-balance sheet items among top financial managers of Hungarian firms has changed over the last decade. The research is based on three samples from 2004, 2009 and 2013, each including around 300 CFOs, each carried out by Corvinus University of Budapest as part of the research program entitled "In competition with the world". While the firms approached and managers answering changed across samples, the wording of the questions remained nearly unchanged, which offers a good opportunity to analyze trends and changes through time.

The term off-balance sheet items is used with various meanings. Some would refer by that only to assets not listed on the balance sheet (like human resource), while others (typically in the case of financial institutions) mainly focus on liabilities (e.g. guarantees). In this article, this term is used in its widest context referring to any item that (1) has an effect on the value of the firm, (2) does not appear in the financial statements at its fair business value, or is not shown there at all, and (3) its value can be influenced by the firm itself. So the term would not only cover liabilities, assets undervalued by accounting and assets not shown in the financial statements at all.

\section{Theoretical Review}

Identifying, grouping, and valuing off-balance sheet assets is a very complex task far beyond the scope of this paper, so only a short review is offered here. A more detailed analysis can be found in Juhász (2004). 
The reason why the business value of a wealth element may be different from its book value is that accounting and finance look at the value from a different point of view. Accounting aims to determine a minimal amount that could be realized even in the worst case and can be supported by written proofs without nearly any doubt. At the same time, finance builds on estimates about the future and calculates an expected (likely) value that could be achieved on average under given assumptions.

There is also a difference relating to what is considered to be a wealth element. Accounting focuses on items only that can be separately sold and bought, finance would consider whatever has an effect on the value of the firm and can be influenced by the company.

Thus, any deviation between the two values is not an error of one or the other system. A detailed review on issues related to accounting treatment of intangibles is offered by Zéghal and Maaloul (2011). Palacios and Galván (2007) present and compare intangible management guidelines across Europe, while Radneantu (2009) and Vidrascu et al. (2014) offer a short overview of possible valuation methods.

A difference between the book value and the financial value of an asset or liability may be due to at least three reasons. The item is (1) shown in the balance sheet but the realistic financial value is different (typically, higher than shown by accounting.) A good example on that would be a real estate purchased several decades ago when inflation meanwhile has pushed market value upwards.

An item may (2) completely miss from the accounting database as the system could not link any appropriate, well-documented value to it. We may have here brands created (with all linked marketing costs expensed) or guarantees offered by the very same firm. Finally, an item could (3) be absent from the accounting system because it is not considered as a wealth element at all. Standfield (2002, p. 48) underlines that quasi assets (like business connections or fame), which have a considerable influence on the business value of the firm but are only manageable and cannot be individually bought or sold (quasi assets) remain outside the accounting system. It is clear that a firm with well-trained employees, flexible suppliers and trustful buyers are of higher value than those with the same assets but without all these connections. Still these quasi assets have usually zero value in case of liquidation (as those cannot be separately sold) so accounting is not willing to allocate value to those.

On the top of all that, we know that to create shareholder value, in other words, positive net present value, firms do only purchase assets for a project if those have lower value altogether than the present value of all future cash flows that determines the business value of the project. So, even if we would allocate a realistic value to all of the assets and liabilities, the total business value of the firm would be higher than the sum of all those individual values. The differences presented are summarized in Figure 1.

There were various attempts to quantify the difference between accounting and financial value. While arriving at very different results, all authors agree on finding an extremely high gap between the two values. After Personnel Today (2002) the book value was on average 98 percent of the market value of listed firms in the US in 1978, but that number fell by 1988 to 28 percent and lowered below 20 percent by the end of the century. Based on Damodaran (2015), we get a book value/market value ratio for the American firms of between 37 and 65 percent for the 2000-2014 period. 
Total fair value of all assets owned

Replacement value of all assets shown

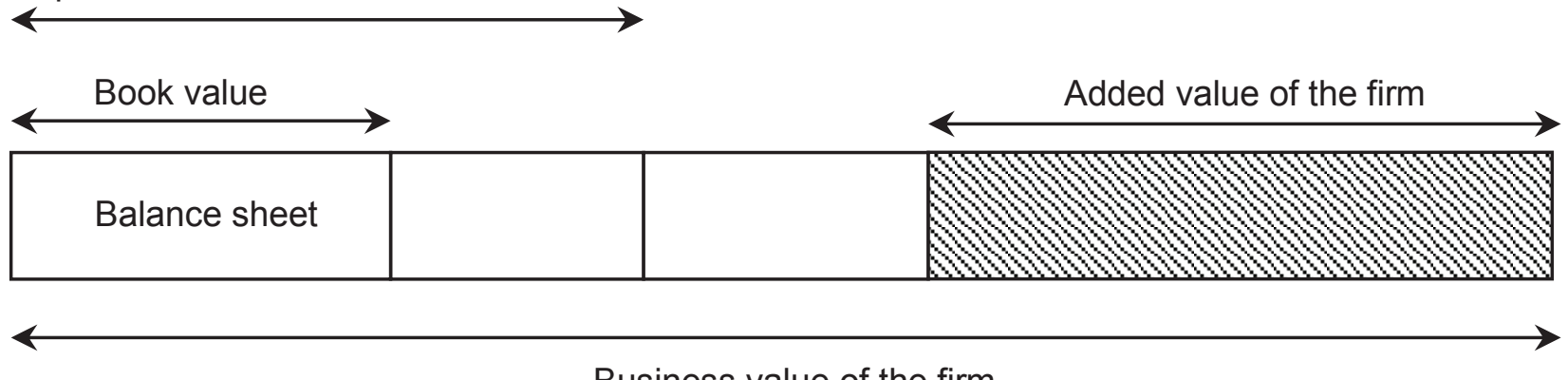

Business value of the firm

Source: author

Why is this difference important? As top financial decision makers are assumed to look after shareholder value creation, they should be exactly aware of the amount of capital invested into current and prospective projects or even the whole firm to judge whether the given investment is worth accepting or continuing. How could one look after the wealth of the firm using the accounting information system only if that covers less than half (even down to 20 percent) of the firm value? That is like driving in twilight without your headlights turned on.

Table 1 | Most typical method used to estimate the amount of invested capital of the business units in the UK

\begin{tabular}{|l|c|}
\hline Measure & Frequency [\%] \\
\hline Net book value & 87 \\
\hline Replacement value & 4 \\
\hline Gross book value & 3 \\
\hline Market value & 1 \\
\hline Other & 5 \\
\hline
\end{tabular}

Source: author, Based on Arnold-Davies (2000, p. 159)

No wonder Arnold and Davies (2000) using questionnaires checked how UK companies would estimate the amount of their invested capital (Table 1). They realized that most of the companies kept on using the accounting estimates for financial decision making. One of the aims of this paper is to investigate whether the Hungarian managers were more advanced a decade later.

Recent empirical research papers on intellectual capital usually either use stock exchange data to estimate market value and compare that to book value reported (see Maditinos at al., 2011 on Greek or Păvăloaia, 2012 on Romanian listed companies, and 
Frey \& Oehler, 2014 on the German market) or build on a couple of case studies offering a more in-depth understanding of individual factors and measurement problems (e.g. Gatti, 2015) on an Italian firm). This research using a statistically considerable amount of questionnaires filled in by CFOs belongs to the third group of papers (a similar techniques is used by Rudež \& Mihalič, 2007 on Slovenian hotels, and Kontić \& Čabrilo, 2009 for measuring intellectual capital in Serbia) and also serves as a possible bridge between the two former approaches.

\section{Methods}

The research program "In competition with the world" started in the middle of the 1990's at Corvinus University of Budapest. Complex questionnaires were filled in by four top managers (CEO, CFO, head of marketing, head of production) of each of the firms selected. Questions on intellectual capital were first added to questionnaires in 2004. Later samples from 2009 and 2013 did not cover exactly the same firms, so no panel could be created. Details of the samples and the whole population are shown in Tables 2 and 3.

Table 2 | The structure of the Hungarian economy and samples

\begin{tabular}{|l|c|c|c|c|c|c|}
\hline \multirow{2}{*}{ Field of activity } & \multicolumn{3}{|c|}{ Whole population* } & \multicolumn{3}{c|}{ Sample } \\
\cline { 2 - 7 } & $\mathbf{2 0 0 4}$ & $\mathbf{2 0 0 9}$ & $\mathbf{2 0 1 3}$ & $\mathbf{2 0 0 4}$ & $\mathbf{2 0 0 9}$ & $\mathbf{2 0 1 3}$ \\
\hline Agriculture & $3.3 \%$ & $3.5 \%$ & $3.8 \%$ & $2.8 \%$ & $4.2 \%$ & $8.0 \%$ \\
\hline Exploitation & $0.1 \%$ & $0.1 \%$ & $0.1 \%$ & $6.9 \%$ & $0.0 \%$ & $0.0 \%$ \\
\hline Manufacturing & $9.0 \%$ & $7.5 \%$ & $7.6 \%$ & $51.2 \%$ & $42.4 \%$ & $45.3 \%$ \\
\hline Energy & $0.3 \%$ & $0.4 \%$ & $0.4 \%$ & $6.9 \%$ & $1.9 \%$ & $4.3 \%$ \\
\hline Construction & $10.4 \%$ & $9.8 \%$ & $8.5 \%$ & $5.5 \%$ & $8.4 \%$ & $7.7 \%$ \\
\hline Trade & $21.6 \%$ & $20.2 \%$ & $21.6 \%$ & $9.7 \%$ & $19.1 \%$ & $20.0 \%$ \\
\hline Service & $49.9 \%$ & $52.6 \%$ & $51.1 \%$ & $12.1 \%$ & $23.0 \%$ & $14.7 \%$ \\
\hline Public services & $5.2 \%$ & $6.2 \%$ & $6.8 \%$ & $4.8 \%$ & $1.0 \%$ & $0.0 \%$ \\
\hline N (number of firms) & 708307 & 688996 & 579579 & 289 & 309 & 300 \\
\hline n.a. & & & & 12 & 0 & 0 \\
\hline N total & & & & 301 & 309 & 300 \\
\hline
\end{tabular}

*Hungarian firms with ongoing operation

Source: Central Statistical Office of Hungary (KSH, 2015) and author

Unfortunately the samples are neither representative for the continuously changing activity structure of the Hungarian economy, nor for company size. However the questionnaire, which was focusing on off-balance sheet assets only, asked for the personal view of the managers and not for details that would be industry or size specific. So, 
when comparing data from samples directly, we assume that samples are random and representative for Hungarian financial managers' view on intellectual property. As for value related estimations, structural changes in activity across samples was corrected with reweighting the sample.

Table 3 | Ownership of firms in the samples

\begin{tabular}{|l|r|r|r|}
\hline (\%) & $\mathbf{2 0 0 4}$ & $\mathbf{2 0 0 9}$ & $\mathbf{2 0 1 3}$ \\
\hline No majority owner & 5.3 & 9.6 & 0.0 \\
\hline Majority state ownership & 28.6 & 9.0 & 5.7 \\
\hline Majority local private ownership & 46.8 & 66.1 & 71.3 \\
\hline Majority foreign private ownership & 19.3 & 15.3 & 23.0 \\
\hline N (number of firms) & 301 & 301 & 300 \\
\hline n.a. & 0 & 8 & 0 \\
\hline N total & 301 & 309 & 300 \\
\hline
\end{tabular}

Source: author

\section{Results}

To see how significant the difference between book and market value of firms in Hungary might be, CFOs were asked to estimate what percentage of the total value certain wealth elements would give (if individual answers did not add up to 100 percent, indicated ratios were proportionally rebalanced to achieve that). As importance of asset types may be different across industries, a reweighted average has also been calculated to keep industry weights of 2004 to control for the structural changes of the samples (Tables 4 and 5).

Table 4 | Structure of firm value after CFO's estimation

\begin{tabular}{|l|c|c|c|c|c|}
\hline (\%) & $\mathbf{2 0 0 4}$ & $\mathbf{2 0 0 9 *}$ & $\mathbf{2 0 1 3}$ & $\mathbf{2 0 0 9} *$ 2013** \\
\hline Real assets, Hungarian firms & 40.6 & 31.2 & 29.1 & 31.1 & 29.8 \\
\hline Financial assets, Hungarian firms & 11.8 & 19.3 & 20.0 & 19.3 & 19.9 \\
\hline $\begin{array}{l}\text { Off balance sheet assets, Hungarian } \\
\text { firms }\end{array}$ & 48.4 & 49.4 & 50.9 & 49.6 & 50.2 \\
\hline $\begin{array}{l}\text { Off balance sheet assets, US listed } \\
\text { firms }\end{array}$ & 63.4 & 44.7 & 44.7 & & \\
\hline $\begin{array}{l}\text { Off balance sheet assets, Romanian } \\
\text { listed firms }\end{array}$ & & 29.2 & & & \\
\hline
\end{tabular}

*Averages reweighted for the industry structure in 2004 ** Original sample averages

Source: author; US: Damodaran (2015); Romania: Păvăloaia (2012) 
Table 5 | Structure of firm value after CFO's estimation

\begin{tabular}{|l|c|c|c|c|c|}
\hline (\%) & $\mathbf{2 0 0 4}$ & $\mathbf{2 0 0 9}$ & $\mathbf{2 0 1 3}$ & $\mathbf{2 0 0 9 * *}$ & $\mathbf{2 0 1 3}$ \\
\hline Off balance sheet total & 48.4 & 49.4 & 50.9 & 49.6 & 50.2 \\
\hline a) Business connections & 15.0 & 16.5 & 16.0 & 16.3 & 15.6 \\
\hline b) Human resource & 14.1 & 13.0 & 16.5 & 13.3 & 16.4 \\
\hline c) Brands & 5.7 & 4.5 & 7.5 & 4.4 & 7.7 \\
\hline d) R\&D & 2.6 & 3.3 & 5.2 & 3.4 & 4.9 \\
\hline e) Other knowledge capital & 11.0 & 12.3 & 5.8 & 12.2 & 5.6 \\
\hline
\end{tabular}

* Averages reweighted for the industry structure in $2004{ }^{* *}$ Original sample averages Source: author

The most important conclusion is, that, after the 900 CFO interviewed, almost half of the business value would not appear in the Hungarian balance sheets during these ten years. This is not very different from what has been measured by Damodaran (2015) for US listed firms (calculated from book value of invested capital over enterprise value, $\mathrm{BV} / \mathrm{EV}$ ratios). Based on stock exchange data, the same database gives an off-balance sheet asset proportion of 27.1 percent for Europe and 25.7 percent for emerging markets for 2014, which is far less than what CFOs in our samples estimated for their non-listed, far smaller firms. The stagnation experienced by the Hungarian managers contrasts with intangibles gaining importance in German stock index (DAX) members from 2005 to 2008 (Frey \& Oehler, 2014) and the general fallback in proportion of intellectual capital in 2011 at Romanian listed firms (Păvăloaia, 2012) that might be also explained by overall undervaluation of the companies due to the financial crisis that time.

This leads to two important implication for managers.

(1) Just by looking at financial statements created by the accounting department almost half of the company value remains hidden. Because of that, it is extremely hard for managers to recognize any loss in that value without a dedicated IC monitoring system.

(2) While capital market fluctuations may make one conclude that IC elements have lost some of their importance, CFOs own experience contradicts that trend. So IC management should be just as important today as before the crisis.

Although over the decade analyzed, the importance of items not shown on the balance sheet has more or less stagnated, there were important changes within the structure of value (Table 5). The role of real assets has decreased while financial assets gained importance. Probably also due to the global crisis but also due to changes in technology, human resource and R\&D activity played a bigger role in 2013 than ten years earlier.

The huge percentage of missing value clearly raises the question whether one could draw an acceptable conclusion based on a financial statement analysis and whether an accounting information system alone would be enough to support value based management. It is clear that the classic accounting measurement problem is present in Hungary (for details on intangible asset reporting of Hungarian firms, see Kovács, 2015). But is 
that pushing firms to add new measures to follow changes in the wealth not monitored by accountants?

In the literature of performance measurement, it is quoted as a classic potential pitfall to enhance the corporate information system by adding new measures but no including those into the decision making process (Amaratunga \& Baldry, 2002). This is why both the option of measuring only and measuring and using at the same time were offered. As Table 6 shows, the classic pitfall seems to appear also in Hungary: 10 to 30 percent of the firms measure something and do not use the results later on.

Table 6 | Individual measurement of (quasi) asset values by type

\begin{tabular}{|c|c|c|c|c|}
\hline Asset type & Year & $\begin{array}{c}\text { Not } \\
\text { measured }\end{array}$ & $\begin{array}{l}\text { Measured } \\
\text { separately }\end{array}$ & $\begin{array}{l}\text { Measured and } \\
\text { used in } \\
\text { decision making }\end{array}$ \\
\hline \multirow{3}{*}{ Human resource } & 2004 & 53.6 & 18.9 & 27.5 \\
\hline & 2009 & 51.1 & 21.9 & 27.0 \\
\hline & 2013 & 68.8 & 16.4 & 14.8 \\
\hline \multirow{3}{*}{ Knowledge capital } & 2004 & 80.9 & 8.7 & 10.5 \\
\hline & 2009 & 73.1 & 16.2 & 10.7 \\
\hline & 2013 & 81.9 & 10.4 & 7.7 \\
\hline \multirow{3}{*}{ Business relations } & 2004 & 62.0 & 14.8 & 23.2 \\
\hline & 2009 & 52.0 & 23.4 & 24.7 \\
\hline & 2013 & 64.0 & 20.6 & 15.3 \\
\hline \multirow{3}{*}{ Supplier connections } & 2004 & 57.5 & 17.1 & 25.4 \\
\hline & 2009 & 48.3 & 25.9 & 25.9 \\
\hline & 2013 & 58.0 & 25.5 & 16.5 \\
\hline \multirow{3}{*}{ Buyer connections } & 2004 & 52.6 & 19.5 & 28.0 \\
\hline & 2009 & 46.4 & 24.0 & 29.6 \\
\hline & 2013 & 53.5 & 28.9 & 17.6 \\
\hline \multirow{3}{*}{ Brands } & 2004 & 78.3 & 11.2 & 10.5 \\
\hline & 2009 & 71.4 & 14.3 & 14.3 \\
\hline & 2013 & 75.0 & 15.2 & 9.8 \\
\hline \multirow{3}{*}{ Real estates } & 2004 & 40.4 & 30.6 & 29.0 \\
\hline & 2009 & 57.0 & 26.1 & 17.0 \\
\hline & 2013 & 66.8 & 19.3 & 13.9 \\
\hline \multirow{3}{*}{ Financial investments } & 2004 & 41.1 & 26.4 & 32.5 \\
\hline & 2009 & 45.1 & 23.9 & 31.0 \\
\hline & 2013 & 61.9 & 21.7 & 16.4 \\
\hline
\end{tabular}

Source: author 
While managers believe the missing part of the value was at least the same in 2013 as in 2004, trends do not show a clear advancement in information system quality. As for probability of measurement, in almost all cases we see an improvement in 2009 that disappears by 2013. Once focusing on decision making, we find a clear fallback: there were fewer and fewer companies really using the outcome of their measurements.

The case of real estate and financial investments is particularly delicate. More than half of the CFOs stated there is no separate measurement system for these assets, while companies are obligated by accounting standards to continuously to keep track of the market value of these items.

Ordering the intellectual capital items according to their likelihood to be measured and involved in the decision making (Table 7), we see the relative importance of buyer, supplier, and business connections grow - a trend that is most probably to be explained by the global crisis. This fits very well with the view of the German accountants based on which Frey and Oehler (2014) state that customer and contract related intangible assets have the highest influence on company performance.

Table 7 | Rank of probability being involved in decision-making

\begin{tabular}{|l|c|c|c|}
\hline & 2004 & 2009 & 2013 \\
\hline Financial investments & 1 & 1 & 3 \\
\hline Real estates & 2 & 6 & 6 \\
\hline Buyer connections & 3 & 2 & 1 \\
\hline Human resource & 4 & 3 & 5 \\
\hline Supplier connections & 5 & 4 & 2 \\
\hline Business relations & 6 & 5 & 4 \\
\hline Brands & 7 & 7 & 7 \\
\hline Knowledge capital & 7 & 8 & 8 \\
\hline
\end{tabular}

Source: author

Kovács (2015) is also complaining about the low amount of non-obligatory intellectual capital information found in her review of annual reports of 2012. Hungarian firms have hardly reported additional information above the requirements of relevant laws and regulations. The most common addition was data on intellectual property (e.g. brands). The next in the row was human resources, followed by strategy and competition, market and customer, then finally R\&D.

When focusing on measurement itself (adding probability of measuring only and that of measuring and using results) in our sample buyer, supplier and business relations still take the lead in 2013 (36 to 46 percent), followed by human resources (31 percent), while brands and knowledge capital lag behind (below 25 percent). So, it seems that even if firms collect additional information on some IC elements, they are not necessary willing to share those results in their annual reports with the rest of the world. The 
probability of disseminating information on brands and human resource is far higher than that of the different business connections, which are most often measured.

Inspired by Arnold-Davies (2000), the measurement methods of invested capital were also surveyed (Table 8). After the answers there is a continuous improvement regarding methods used contrary to the likelihood of measurement of IC items. The increased popularity of market value may be partly due to the more extended use of fair value accounting using which book value and market value show little difference.

Table 8 | Most typical method used to estimate the amount of invested capital

\begin{tabular}{|l|c|c|c|c|}
\hline & $\begin{array}{c}\text { UK } \\
\mathbf{2 0 0 0}\end{array}$ & $\begin{array}{c}\text { Hungary } \\
\mathbf{2 0 0 4}\end{array}$ & $\begin{array}{c}\text { Hungary } \\
\mathbf{2 0 0 9}\end{array}$ & $\begin{array}{c}\text { Hungary } \\
\mathbf{2 0 1 3}\end{array}$ \\
\hline Net book value & $87.0 \%$ & $59.3 \%$ & $53.3 \%$ & $45.8 \%$ \\
\hline Replacement value & $4.0 \%$ & $5.5 \%$ & $3.2 \%$ & $12.0 \%$ \\
\hline Gross book value & $3.0 \%$ & $12.3 \%$ & $17.8 \%$ & $7.3 \%$ \\
\hline Market value & $1.0 \%$ & $22.0 \%$ & $23.6 \%$ & $33.3 \%$ \\
\hline Other & $5.0 \%$ & $1.0 \%$ & $2.2 \%$ & $1.6 \%$ \\
\hline
\end{tabular}

*Answers were proportionally reweighted to add up to 100 percent

Source: author, UK: Arnold-Davies (2000, p. 159)

\section{Conclusions}

Comparing three questionnaire-based research projects including answers of $900 \mathrm{CFOs}$ from over a decade, the view on off-balance sheet assets has been examined in Hungary. The main findings of this paper can be summarized as follows.

(1) According to the managers' opinion, half of the company value was missing from the financial statements during the decade analyzed, a rate well above the market rates of emerging countries and similar to the one measured in capital markets of more developed countries, like the US.

(2) Still, detailed measurement of individual IC elements became rarer, and the information base of decision-making became narrower. The probability of sharing results with outsiders in annual reports differs heavily along asset type: information on brands and human resources is more likely to be published than details of business connections. Hungarian financial managers most often use the value of the same intellectual assets in decision making that are considered to be the most important also by German CPAs.

(3) While more advanced measurement techniques became popular, 10 to 30 percent of the firms tend to measure the value of an IC element without integrating the results into their decision making.

(4) Surprisingly, based on the answers of the CFOs, firms tend to use more advanced methods to track the value of assets, at least whatever they do track. An explanation of this could be the more extended use of fair value accounting, which uses more or less the market value as book value. 
It seems that more than two-thirds of the Hungarian firms do not actively consider value changes in their IC elements, thus not considering almost half of the business value of their company. It is very hard if not impossible to maximize shareholder value in such a working environment, so more care should be taken to improve information systems and educate top management further.

These findings may offer a connecting mezzo level to link earlier case study based qualitative results and capital market or country level quantitative researches. Comparing these results to similar researches from other countries and repeating the same study in 3-4 years to describe the long-term trends offer further chance for a more detailed understanding of the processes behind.

\section{References}

Amaratunga, D., \& Baldry, D. (2002). Moving from performance measurement to performance management. Facilities, 20, 217-223.

Damodaran, A. (2001). The dark side of valuation: valuing old tech, new tech, and new economy companies. London: Prentice Hall.

Damodaran, A. (2015). Archived Data, Value to Book ratios. Retrived: December 31, 2015, from http://pages.stern.nyu.edu/ adamodar/

Frey, H., \& Oehler, A. (2014). Intangible assets in Germany: Analysis of the German stock market index DAX and a survey among the German Certified Public Accountants. Journal Of Applied Accounting Research, 15(2), 235-248.

Gatti, M. (2015). Exploring the challenges of measuring intangibles: The implementation of a balanced scorecard in an Italian company. International Journal Of Management Cases, 17(4), 120-133.

Juhász, P. (2004). The explanation of the difference between the book value and the business value - Valuation problems of the off-balance sheet items of companies. PhD dissertation, Budapest: Corvinus University of Budapest, PhD program Management and Business Administration.

Kontić, L., \& Čabrilo, S. (2009). A strategic model for measuring intellectual capital in Serbian industrial enterprises. Ekonomski Anali / Economic Annals, 54(183), 89-117.

Kovács, Zs. I. (2015). Immaterial Assets in the Hungarian Accounting System and Financial Statements. Public Finance Quarterly (0031-496X), 62(2), 226-237.

KSH (2015). Müködö, valódi új, valódi megszűnt vállalkozások száma nemzetgazdasági ág szerint (2003-). [Number of operating, new and terminated businesses across fields of activity] Központi Statisztikai Hivatal (Central Statistical Office, Hungary) Retrived: December 30, 2015, from https://www.ksh.hu/docs/hun/xstadat/xstadat_eves/i_qpg008.html

Maditinos, D., Chatzoudes, D., Theriou, G., \& Tsairidis, C. (2011). The impact of intellectual capital on firms' market value and financial performance. Journal Of Intellectual Capital, 12(1), 132-151.

Palacios, T. M. B., \& Galván, R. S. (2007). Intangible measurement guidelines: a comparative study in Europe. Journal Of Intellectual Capital, 8(2), 192-205.

Păvăloaia, L. (2012). Research on the appraisal or intangible assets in Romanian companies. CES Working Papers, 4(3), 396-406.

Personnel Today (2002). Getting the measure of human capital. Personnel Today. September 24, 26-30. 
Radneantu, N. (2009). Making the invisible visible: The intangible assets recognition, the valuation and reporting in Romania. Annals of the University of Petrosani Economics, 9(2), 221-226.

Rudež, H. N., \& Mihalič, T. (2007). Intellectual capital in the hotel industry: A case study from Slovenia. International Journal Of Hospitality Management, 26(1), 188-199.

Shapiro, A. C., \& Balbirer, S. D. (2000). Modern corporate finance: a multidisciplinary approach to value creation. Upper Saddle River: Prentice Hall.

Standfield, K. (2002). Intangible management: tools for solving the accounting and management crisis. Boston: Academic Press.

Vidrascu, P., Cristea, A. M., lacob, O.C., \& Volintiru, A. (2014). Synthesizing and exposure of the assessment methods of the intangible assets. Internal Auditing \& Risk Management, 9(3), 78-88.

Zéghal, D., \& Maaloul, A. (2011). The accounting treatment of intangibles - A critical review of the literature. Accounting Forum, 35(4), 262-274.

\section{Author}

\section{Péter Juhász, PhD, CFA}

Associate Professor

Department of Finance, Faculty of Business Administration

Corvinus University of Budapest

Fővám tér 8, 1093 Budapest, Hungary

peter.juhasz@uni-corvinus.hu 